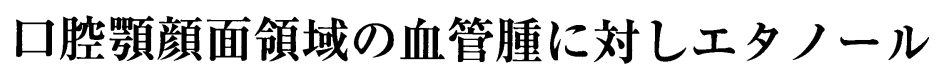 局所注入療法を行った 2 症例
}

\author{
石川均 ${ }^{1)}$ 長谷川和 樹 ${ }^{2)}$ 宮本日出雄 ${ }^{2)}$

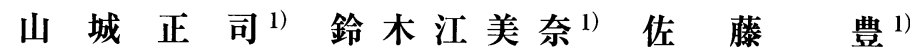 \\ 天 笠 光 雄 ${ }^{1)}$
}

\begin{abstract}
要旨：口胿顔面領域の血管腫の治療においては, 術前の機能性, 審美性を損なうことがないようその選択に苦虑する ことが多い。われわれは, 舌, 下唇，㚘粘膜の血管腫 2 症例に対し術前に Dynamic MRI 検查を行ったところ, lowflow type の血管腫と診断されたため, エタノールの局所注入療法を行った。2 症例とも機能性, 審美性を損なうこと なく腫瘍の消失または縮小の効果を得ることができた。2 症例については, いずれも女性で年齢は 54 歳, 24 歳で, 部 位は舌, 下唇拉よび煩粘膜であった。
\end{abstract}

キーワード：血管腫，血管奇形，エタノール局所注入療法，ダイナミック MRI

\section{緒言}

血管腫は，日常診療で遭遇する機会が少なくない良性腫 瘍である。これまで口䏕顔面領域の血管腫の治療には, 切 除療法, 梱包療法, 凍結外科療法など様々な治療法が行わ れてきている。しかし腫瘍に対する縮小, 消失効果とあわ せ局所の機能性, 審美性も考慮しなければならず, その治 療法の選択には苦虑することが多い。

今回われわれは, 腎囊胞 ${ }^{1)}$, 肝癌 ${ }^{2)}$ の治療に用いられて いる液体硬化物質であるエ夕ノールを用い口腔顔面領域の 血管腫 2 症例に局所注入療法を行い形態と機能を温存しつ つ腫瘍の消失または縮小寸ることができたのでその概要を 報告する。

\section{症例 1}

患者: 59 歳, 女性。

初診 : 2000 年 7 月 31 日。

主訴：下唇および舌の腫脹。

既往歴・家族歴：特記事項なし。

現病歴：約 20 年前, 血管腫の診断で静岡市立静岡病院 口胿外科にて凍結療法を行い, 腫瘍は縮小したが, その後 来院しなかった。2000 年 7 月歯科治療目的にて近歯科を 受診したところ，血管腫を指摘され静岡市立病院口胿外科 を紹介され受診となった。

現症：両側下唇, 舌尖部, 左側舌縁および左口底に暗赤

\footnotetext{
1) 東京医科歯科大学大学院医歯学総合研究科・顎顔面頸部機能再建 学系·顎顔面機能修復学・顎顔面外科学分野 (主任 : 天笠光雄教授)

2) 静岡市立静岡病院口腔外科（主任：長谷川和樹科長）

〔受付 : 2005 年 2 月 28 日, 受理 : 2005 年 3 月 25 日〕
}

色の病変を認めた (写真 1)。2000 年 8 月 12 日 Dynamic MRI 施行。Low-flow type の血管腫 と診断された。

臨床診断：両側下唇, 舌尖, 左側舌縁血管腫。

処置および経過： 2000 年 9 月 17 日入院。9 月 19 日全身 麻酔下にエタノールの局所注入療法を施行した。術式は, 腫瘍の中枢側を手指で圧迫して血管病変を怒張させた。怒 張した病変の中心部を穿刺し，病変から血液が吸引できる ことを確認した。吸引しえた血液量の $1 / 3$ 程度の滅菌無水 エタノールを注入した。注入後，バイタルサインの変化を 観察しながら穿刺部を含め, 約 10 分程度, 周囲をそのま ま圧迫した。本症例では，下唇血管性病変には右側からそ れぞれ $0.3 \mathrm{ml}, 0.5 \mathrm{ml}, 0.3 \mathrm{ml}$ ，また舌の血管性病変には右 側舌尖部 $1.8 \mathrm{ml}$, 左側舌尖部 $2.3 \mathrm{ml}$, 左舌縁部 $1.0 \mathrm{ml}$ の滅菌 無水エタノールを注入した。術後, 左舌縁部の血管性病変 は，一部に壊死を生じたが, 舌の形態に大きな変化を認め ることなく術後 3 か月程で病変は消失した (写真 2$)$ 。なお, 左舌縁から口底部にかけての病変は縮小を認めたが，消失 には至らなかった。術後下唇, 舌の知覚, 運動に障害は認 められず, 審美性, 機能性を損なうことなく腫瘍の消失, 縮小が得られた。本治療結果について，患者の満足度は高 く, 2004 年 12 月現在外来にて経過観察を行っているが腫 瘍の増大傾向は認めらない。

\section{症例 2}

患者: 24 歳, 女性。

初診 : 2003 年 4 月 10 日。

主訴：右側頪粘膜の腫脹。

既往歴：特記事項なし。

家族歴：特記事項なし。

現病歴：2歳の頃, 右側口角内側に大きさ $2 \mathrm{~mm}$ 程度の 


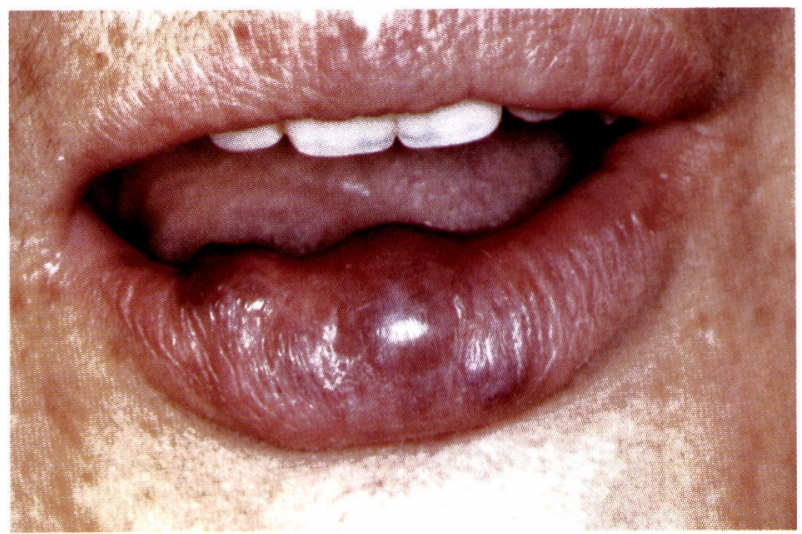

a. 術前の下唇：下唇正中および右側にやや暗紫色を呈する 病変を認める。

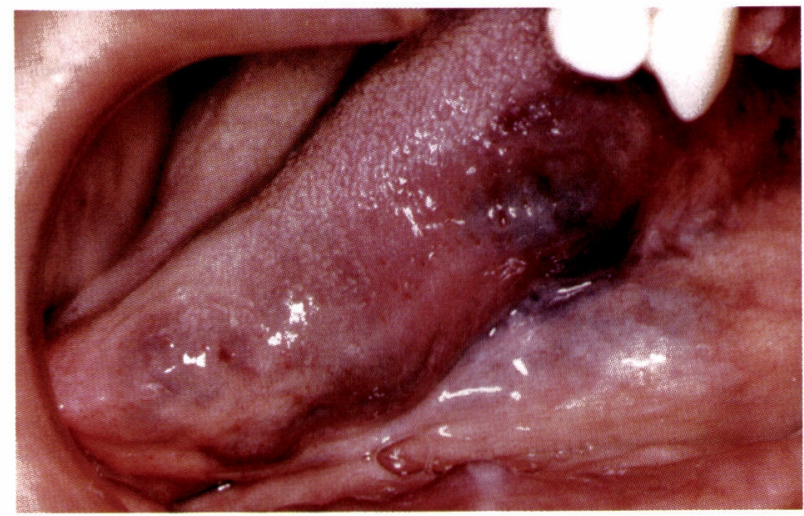

b. 術前の左側舌縁および口底：舌縁から口底にかけて暗紫 色を呈する病変を認める。

写真 1 症例 1 の術前の状態

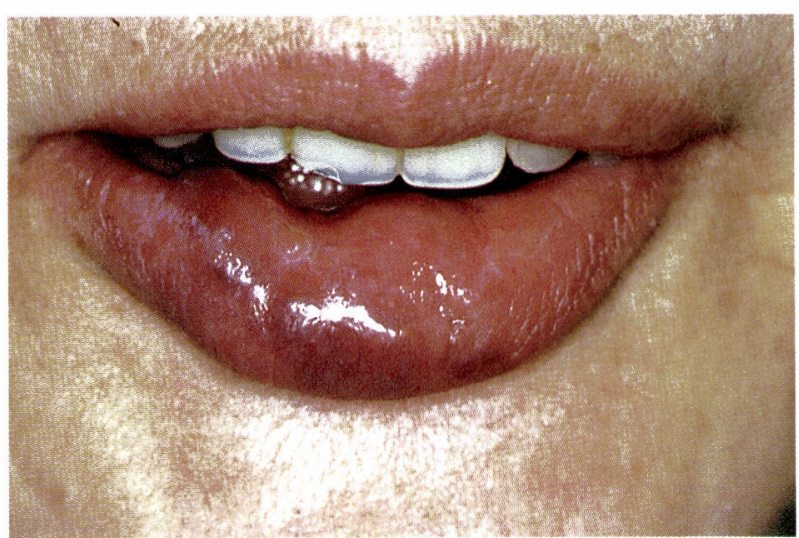

a. 術後の下唇 : 術前に比べ暗紫色の病変は縮小するも完全 に消失していない。

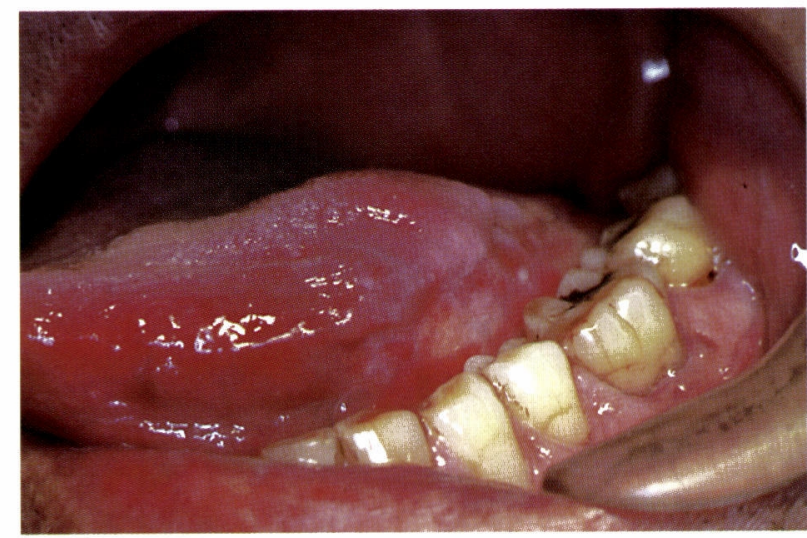

b. 術後の左側舌縁：病変はほぼ消失している。

写真 2 症例 1 の術後の状態

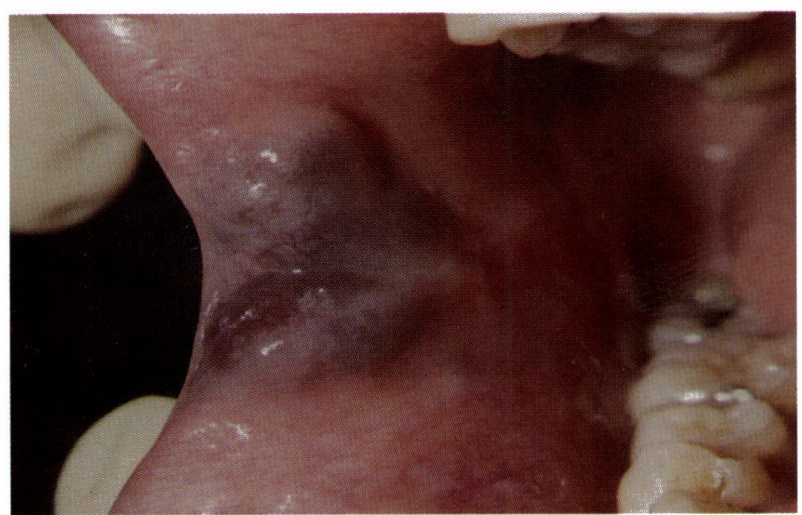

写真 3 症例 2 の術前の煩粘膜の状態

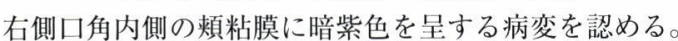

血管腫を近医にて指摘される。その後, 病変は徐々に増大 し中学生頃当科来院し右側煩粘膜血管腫と診断受けるも処 置せず経過観察となった。2003 年 4 月近歯科受診し, 同 病変について相談したところ，東京医科歯科大学歯学部附 属病院顎顔面外科受診を勧められ，2003 年 4 月 10 日当科 再受診した。

現症：右側口角内側に $19 \times 17 \mathrm{~mm}$ 大の暗赤色の病変を 認めた（写真 3)。2003 年 4 月 21 日 Dynamic MRI 施行。 Low-flow type の血管腫と診断された。

臨床診断：右側煩粘膜血管腫。

処置および経過：2003 年 5 月 15 日全身麻酔下にエ夕 ノール局所注入療法を施行した。 $0.8 \mathrm{ml}$ の滅菌無水エ夕 ノールを注入した。術後 3 日目には, 病変部の粘膜上皮は 壊死しはじめ, 術後 11 日目には腫湯自体が壊死脱落し上 皮の欠損が生じた（写真 4)。術後 17 日目には，欠損部は 


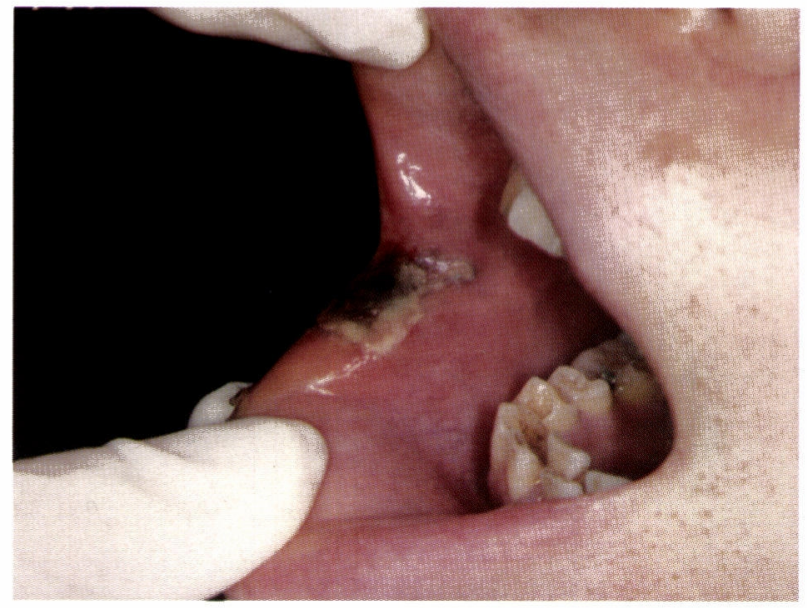

a. 術後 3 日目の病変部 : 病変の上皮に壊死組織を認める。

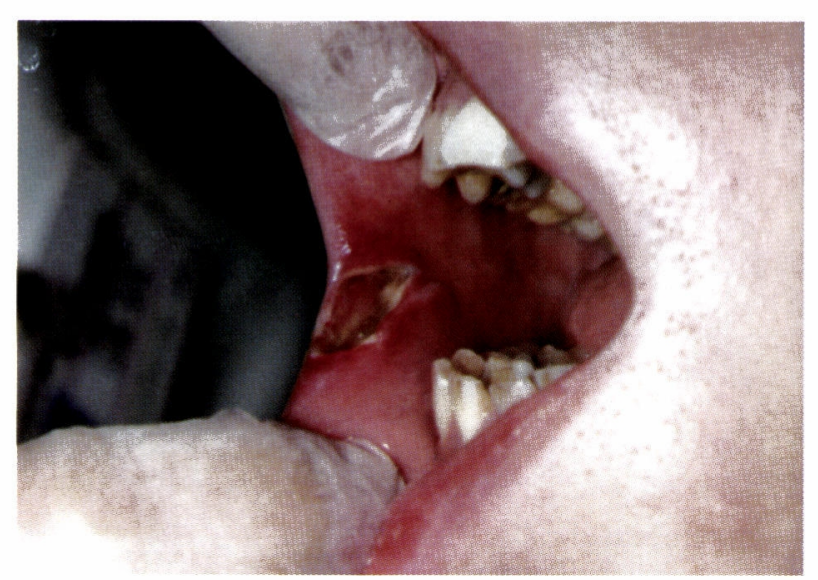

b. 術後 11 日目の病変部：病変は完全に壊死脱落し, 粘膜の 欠損を認める。

写真 4 症例 2 の術後経過 -1

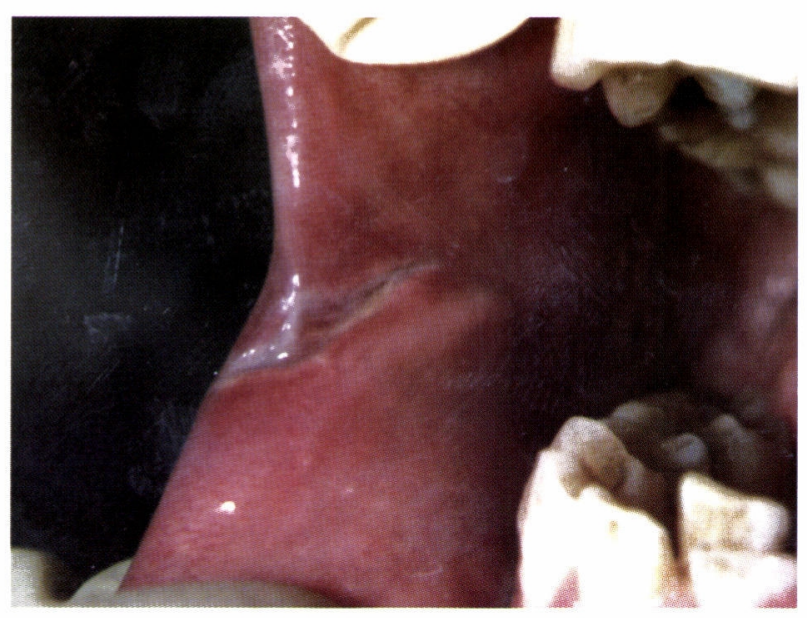

a. 術後 17 日目の病変部：欠損部はほぼ上皮化している。

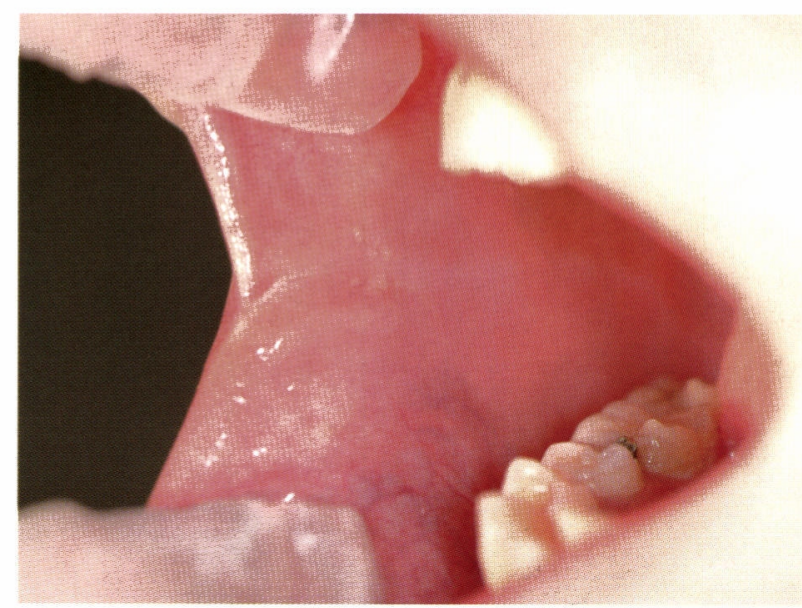

b. 術後 6 か月の右側頪粘膜の状態：血管腫は完全に消失し 正常な粘膜になっている。

写真 5 症例 2 の術後経過 -2

ほほ治癒し，術後 6 か月では機能性，審美性を損なうこと なく病変の消失が認められた（写真 5)。2004 年 12 月現在 外来にて経過観察中である。

\section{考察}

従来, 血管腫は単純性, 蔓状, 海綿状, その他に分類 されていが, 1980 年代から病理組織学的に血管内皮細胞 の増殖を認めるものを hemangioma, 内皮細胞の増殖が なく異型な血管の集合からなるものを vascular malformation と定義している ${ }^{3-5)}$ 。今回の症例では, 生検していな いので，血管腫の組織（亜）型は不明であった。vascular
表 1 flow type による血管腫の治療法

\begin{tabular}{cc}
\hline flow type & 血管腫治療法 \\
\hline high & 塞栓療法 \\
intermediate & 硬化療法と塞栓療法の併用 \\
low & 硬化療法 \\
\hline
\end{tabular}

malformation は, 血管性病変の血流速度と動脈構成側静脈構成側間のシャント率から high-flow type, low-flow type に分類される。また川那部ら ${ }^{6)}$ は, 病変内血流通過 時間から high-flow, low-flow type の中間のものとして, intermediate-flow typeを提唱した。またflow type 別の 
表 2 硬化療法と切除療法の比較

\begin{tabular}{ccc}
\hline & 硬化療法 & 切除療法 \\
\hline 大きさ & 大きいものも縮小 & 大きいものは再建を要する \\
& 硬化期待できる & \\
出血 & ほとんどみられない & 時として多量 \\
術後の瘏痕形成 & 少ない & 必発 \\
適応部位 & 舌前方, 赤唇, 㚘粘膜 & 手術可能な部位 \\
治療回数 & 複数回を要することがある & 少ない \\
\hline
\end{tabular}

治療法をも提唱し, high-flow type には塞栓療法中心に, intermediateflow には塞栓療法と硬化療法の併用を, lowflow type には硬化療法がよいとしている（表 1）。

造影剂を経静脈性に急速注入し, 経時的に観察するダ イナミック MRI は, 病変の血流情報, 拡がり, 深達度な どが明らかになり，flow type を把握できる。今回の 2 症 例にエタノールの局所注入療法を適応した理由としては, 術前のダイナミック MRI からいずれの血管性病変も lowflow type の血管腫が示唆されたこと, 審美性, 機能性を 考慮すべき部位に病変が存在したことによる。

口望顔面領域の血管腫に対しするエタノール療法は,

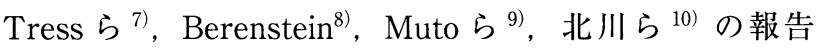
がある。高濃度のエタノール作用は, 血液細胞成分および 血管内皮細胞に対する細胞毒として作用し, 細胞の虚血性 壊死が生じるとされている ${ }^{11,12) 。 ~}$

本療法の利点としては, 切除療法, 梱包療法に比べ手技 が簡単であり, 腫瘍に対する縮小, 消失効果と併せて局所 の審美性，機能性を損傷する可能性が少ないことである。 一方, 欠点としては, 術後の著明な腫脹, 疼痛 ${ }^{6)}$, 刺入針 やエタノールの直接的な神経損傷の可能性などが考えられ る。佐々木ら ${ }^{13)}$ は, 切除療法と比較し硬化療法は, 血管 腫腫が神経・筋肉に隣接浸潤している場合でも, 複数回の 治療を行うことで, 病変を段階的に治療することが可能で あり, また出血, 痏痕形成などの問題が少なく, 完全治癒 が得られない場合でも，二次的な外科切除が容易になると している。われわれは, 本療法の適応部位として舌前方 部, 㚘粘膜, 赤唇部が望ましいと考えている。また, 病変 が大きい場合は, 複数回の硬化療法を行い段階的縮小・消 失させるのが望ましいと考えている（表 2)。

症例 1 では, 下唇および舌尖部の病変は, 患者の満足が 得られる程度の消失・縮小効果を認めたが, 左舌縁から口 底部病変は消失が認められなかった。その原因としては, 術後の腫脹による呼吸障害を考慮し注入量を少なくしたこ とが考えられる。ただし，ある程度の縮小効果は得られ， 審美性のみならず, 縮小による機能面での改善も得られ た。症例 2 では, 病変は審美性, 機能性を損なうこと消失 し，患者の满足する効果が得られた。

本療法は, 局所麻酔下にも施行が可能であると考えてい
る。しかし, 病変部に高濃度のエタノールを直接注入する ため, 短時間に高濃度のエタノールが体循環に流れる可能 性がり，安全をきして，今回の 2 症例は全身麻酔下に本療 法を施行した。幸いにも，術中に著明な腫脹やバイタルサ インの大きな変動は認めなかった。病変が大きい場合, 注 入量も多くなるため全身麻酔下の処置が望ましいと考えて いる。

注入後の著明な腫脹による気道閉塞などを考慮した場 合, 口底や舌後方の血管性病変に対して本療法は慎重に行 わなければならないと考えられる。本療法の合併症となり うる組織壊死，神経損傷は，注入量，治療回数を考虑すれ ば避けられるのではないかと考えている。

\section{結 語}

エタノールの局所注入療法は, 腫瘍に対する縮小, 消失 効果と併せて局所の機能性，審美性を損なうことの少ない 口腔顔面領域の血管腫の有用な治療法の一つとなる可能性 があると考えられたので報告した。

本論文の要旨は, 第 59 回日本口胿科学会総会 (2002 年 5 月 10 日，大阪）において発表した。

\section{文献}

1) Bean, W.J.: Renal cysts: Treatment with alcohol. Radiol $138: 329-331,1981$.

2）杉浦信之, 高良健司, 他：超音波映像下経皮的腫瘍内工夕 ノール注入による小肝細胞癌の治療。肝臓 $24: 920,1983$.

3) Enjolras, O.: Classification and management of the various superficial vascular anomalies: Hemangiomas and vascular malformations. J Dermatol 24 : 701-710, 1997.

4) Mulliken, J.B., Glowacki J.: Hemangiomas and vascular malformations in infants and children: A classification based on endothelial characteristic. Plast Reconstur Surg 69 :412420, 1982.

5) Jackson, I.T., Carreño, R., et al.: Hemangiomas, vascular malformation and lymphovenous malformations; Classification and methods of treatment. Plast Reconstr Surg $91: 1216^{-}$ 1230, 1993.

6）川那部岳志, 脇田進一, 他 : 口唇血管腫 - 血管奇形の治療経 験；硬化療法を中心として. 日形会誌 $16 ： 852-862,1996$. 
7) Tress, B.M., Wilson, J.L. et al.: Ablation of Head and Neck Cavernous Haemangiomas by Direct Alcohol Injection. J Intervent Radiol 2:147-150, 1987.

8) Berenstein, A.: Discussion for "The Treatment of CapillaryVenous Malformation Using a New Fibrosing Agent." Plast Reconstr Surg $71:$ 613-614, 1983.

9) Muto, T., Kinehara, M. et al.: Therapeutic Embolization Oral Hemangiomas With Absolute Ethanol. J Oral Maxillofac Surg $48: 85-88,1990$.

10）北川善政, 橋本賢二, 他 : 口胿顔面領域の血管腫に対するエ 夕ノール局所注入療法の経験. 日口外誌 39:1222-1227.
1993.

11) Lasjaunis $P$, Berenstein A.: Craniofacial hemangioma, Vascular Malformations and Angiomatosis. Surgical Neuroangiography 2, pp40-42, Springer-Verlag, Berlin, 1987.

12）辻口幸之助, 今井啓介, 他：頭頸部顔面領域における venous malformationの治療法一エ夕ノール注入を中心とし て一. 形成外科 $42: 133-138,1999$.

13）佐々木了, 大久促佳子, 他: Vascular malformation の分類 と治療：硬化療法 $44: 637-645,2001$. 


\title{
Two Cases of Direct Ethanol Injection Therapy for Hemangioma in the Oral and Maxillofacial Region
}

\author{
Hitoshi Ishikawa $^{1)}$, Kazuki Hasegawa ${ }^{2)}$, Hideo Miyamoto ${ }^{2)}$ \\ Masashi Yamashiro ${ }^{1)}$, Emina Suzuki ${ }^{1)}$, Yutaka Satou ${ }^{1)}$, \\ and Teruo Amagasa ${ }^{1)}$ \\ 1) Maxillofacial Surgery, Maxillofacial Reconstruction and Function, Division of Maxillofacial \\ and Neck Reconstruction, Graduate School, Tokyo Medical and \\ Dental University (Chief: Prof. Teruo Amagasa) \\ ${ }^{2)}$ Department of Oral and Maxillofacial Surgery Shizuoka City Hospital
}

(Chief: Kazuki Hasegawa)

\begin{abstract}
The selection of treatment is difficult in cases with hemangioma in the oral and maxillofacial region, in the order to preserve the preoperative function and esthetics of the organs. We planned to treat two cases of hemangioma in the tongue, lower lip and buccal mucosa with direct ethanol injection therapy. As these two cases were classified as lowflow type by hemangioma preoperative Dynamic MRI, we decided to treat these two cases with direct ethanol injecttion therapy. We achieved the reduction or disappear ance of the tumor without any functional or esthetic disorders.

Key words : hemangioma, vascular malformation, direct ethanol injection therapy, Dynamic MRI

Requests for reprints to: Dr. Ishikawa H., Maxillofacial Surgery, Maxillofacial Reconstruction and Function, Division of Maxillofacial and Neck Reconstruction, Graduate School, Tokyo Medical and Dental University, 1-5-45, Yushima, Bunkyou-ku, Tokyo 113-8549, Japan
\end{abstract}

